\title{
Effects of River Inputs on Mediterranean Coastal Shore Line in front of Damietta Estuary
}

\author{
A.M. Hassan, M.H. Ali", A.M. Kotb and G.G. Soliman ${ }^{* *}$ \\ Faculty of Science, Al-Azher University, "National Institute of \\ Oceanography and Fisheries and ${ }^{* *}$ Dara Petroleum Company, \\ Ministry of Petroleum (EGPC), Egypt.
}

\begin{abstract}
7 HE WATER quality characteristics and some heavy metals cations $\left(\mathrm{Fe}^{2+}, \mathrm{Mn}^{2+}, \mathrm{Zn}^{2+}, \mathrm{Cu}^{2+}\right.$ and $\left.\mathrm{Pb}^{2+}\right)$ of Damietta estuary and in front of Mediterranean coastal shoreline were evaluated through four successive cruises (February 2008 to November 2008). Twelve sites were selected from the two sectors. The results obtained showed that serious deterioration of quality of water at Damietta estuary compared with Mediterranean shoreline. The concentrations of major cations and anions increased progressively while moving away from Damietta Estuary to the sea which reflect the effect of seawater intrusion into estuary. Contrarily, nutrient salts values in the estuary showed elevated values due to heavily polluted waste water poured into estuary where the nutrient salts content of the Mediterranean Sea water depend on its levels in Damietta Estuary. The distribution order of heavy metals concentrations in water samples was $\mathrm{Fe}>\mathrm{Mn}>\mathrm{Pb}>$ $\mathrm{Zn}>\mathrm{Cu}>\mathrm{Cd}$.
\end{abstract}

The River Nile is the life artery of Egypt. Throughout the known Egyptian history, the Nile had dominating influences on the economy, culture, public health, social life and political aspects ${ }^{(1)}$. At the north of Cairo at Delta Barrage the river Nile bifurcates into two branches namely Damietta and Rosetta. However, the construction of the High Dam resulted in great modification in the hydrodynamic regime of the River Nile, with significant changes in physicalchemical and biological characteristics of the downstream water ${ }^{(2,3)}$.

During recent years serious concern has been voiced about rapidly deteriorating state of the aquatic environment with respect to heavy elements pollution. In addition, the heavy elements in waters may be undergoing rapid changes affecting the rate of uptake or release by sediments ${ }^{(4)}$.

Shaaban Dessouki et al. ${ }^{(5)}$. investigated the environmental parameters and nutrient salts in the Damietta estuary of River Nile. They showed that both electrical conductivity (11.6- $41.8 \mathrm{mmhos} / \mathrm{cm})$ and chlorosity $(8-21.6 \mathrm{gl} / \mathrm{l})$ more or less have the same trend as water salinity. The concentration of nutrient salts showed a wide range of fluctuation and abrupt change due to irregular influxes of different wastes. High and abnormal concentrations of ammonia, nitrate, organic nitrogen and organic phosphorus were recorded, the chemical concentrations of the most parameters in Damietta Branch were increased northward ${ }^{(6)}$. 
Heavy metals are among the most common environmental pollutants, and their occurrence in waters and biota indicates the presence of natural or anthropogenic sources. The main natural sources of metals in waters are chemical weathering of minerals and soil leaching. The anthropogenic sources are associated mainly with industrial and domestic effluents, urban storm, water runoff, and inputs rural areas. Water pollution due to trace metals is an important factor in both geochemical cycling of metals and in environmental health. The existence of heavy metals in aquatic environments has led to serious concerns about their influence on plant and animal life. The nutritional requirements of elements $(\mathrm{Cu}, \mathrm{Zn} . .$. , etc.) differ substantially between species or elements, and optimum ranges of concentrations are generally narrow. Given elements $(\mathrm{Pb}, \mathrm{Cd}$ etc.) exhibit extreme toxicity even at trace levels ${ }^{(7)}$.

The assessment of environmental quality with respect to heavy metals in aquatic systems involves the measurement of a series of metals in water, sediments and living organisms ${ }^{(8,9)}$. Some of heavy metals are classified biochemically as essential elements in the bodies of living organisms and aquatic plants when present in trace amounts. However, they become toxic at high concentrations ${ }^{(10)}$.

The aim of the current study is to clarify the spatial and temporal variation in nutrient and heavy metal concentrations in water in Damietta estuary Branch at Nile Delta. Furthermore, the role of pollutant sources in catchment of Damietta Branch on the water quality was assessed, the interrelationships between heavy metal concentrations were analyzed as well.

\section{Material and Methods}

Six stations were selected to cover Damietta estuary and another six stations were selected to cover the Mediterranean coastal line. Two samples (surface and bottom) were collected from each station during February 2008 until November 2008. Location and characteristics feature of each station are given in Table 1. Water samples were kept into a 2 liter polyethylene bottle in ice box and analyzed in the laboratory.

TABLE 1. Location and characteristics feature of each station .

\begin{tabular}{|c|c|c|c|}
\hline & \multirow[b]{2}{*}{ Station No. } & \multicolumn{2}{|c|}{ Position } \\
\hline & & Latitude & Longitude \\
\hline \multirow{6}{*}{ 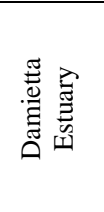 } & I & $31^{\circ} 24^{\prime} 36.14^{\prime \prime}$ & $31^{\circ} 47^{\prime} 12.49^{\prime \prime}$ \\
\hline & II & $31^{\circ} 25^{\prime} 5.55^{\prime \prime}$ & $31^{\circ} 48^{\prime} 35.83^{\prime \prime}$ \\
\hline & III & $31^{\circ} 27^{\prime} 32.10^{\prime \prime}$ & $31^{\circ} 48^{\prime} 6.77^{\prime \prime}$ \\
\hline & IV & $31^{\circ} 28^{\prime} 33.05^{\prime \prime}$ & $31^{\circ} 49^{\prime} 39.26^{\prime \prime}$ \\
\hline & $\mathrm{V}$ & $31^{\circ} 30^{\prime} 12.78^{\prime \prime}$ & $31^{\circ} 50^{\prime} 0.52^{\prime \prime}$ \\
\hline & VI & $31^{\circ} 32^{\prime} 3.11^{\prime \prime}$ & $31^{\circ} 50^{\prime} 40.84^{\prime \prime}$ \\
\hline \multirow{6}{*}{ 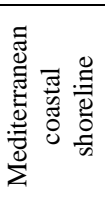 } & VII & $31^{\circ} 31^{\prime} 22.69^{\prime \prime}$ & $31^{\circ} 52^{\prime} 2.29^{\prime \prime}$ \\
\hline & VII & $31^{\circ} 31^{\prime} 20.22^{\prime \prime}$ & $31^{\circ} 54^{\prime} 5.80^{\prime \prime}$ \\
\hline & IX & $31^{\circ} 30^{\prime} 54.90^{\prime \prime}$ & $31^{\circ} 56^{\prime} 50.27^{\prime \prime}$ \\
\hline & $\mathrm{X}$ & $31^{\circ} 29^{\prime} 41.62^{\prime \prime}$ & $31^{\circ} 47^{\prime} 5.21^{\prime \prime}$ \\
\hline & $\mathrm{XI}$ & $31^{\circ} 29^{\prime} 11.09^{\prime \prime}$ & $31^{\circ} 45^{\prime} 23.46^{\prime \prime}$ \\
\hline & XII & $31^{\circ} 28^{\prime} 29.13^{\prime \prime}$ & $31^{\circ} 43^{\prime} 8.94^{\prime \prime}$ \\
\hline
\end{tabular}

Egypt. J. Chem. 55, No.1 (2012) 


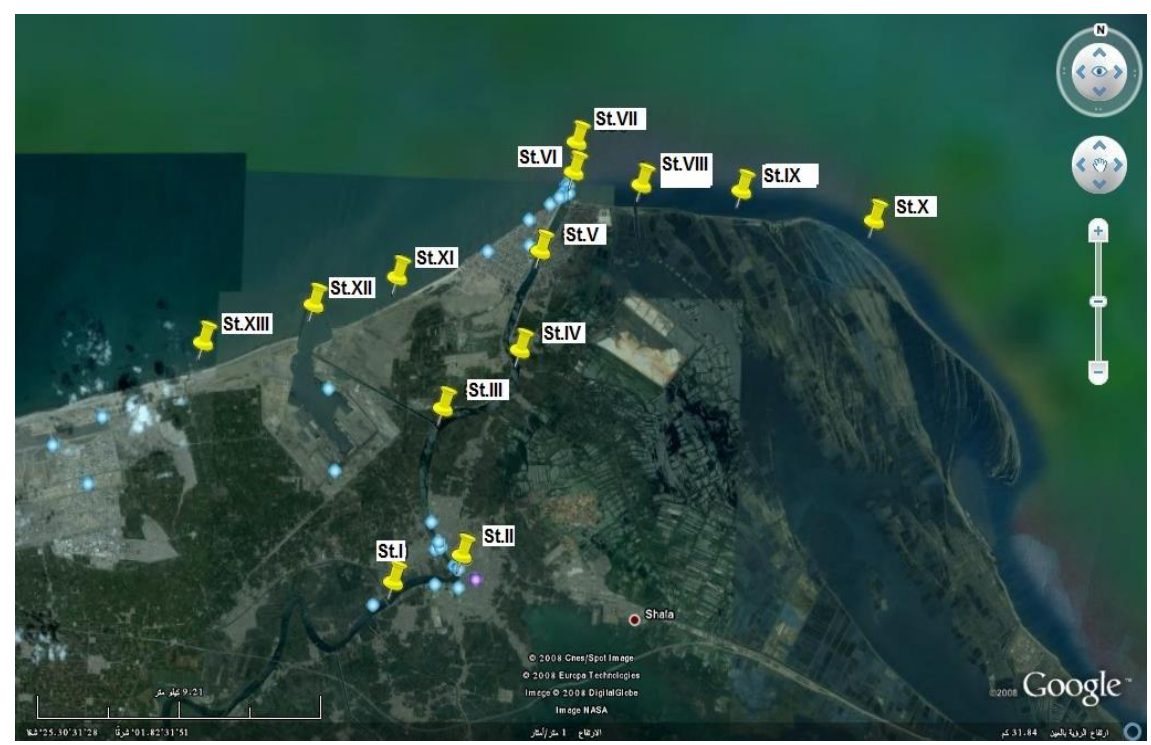

Fig. 1. Map showing the sampling sites along Damietta and Rosetta branches.

Field measurements

Water temperature, $\mathrm{pH}$ value and electrical conductivity were measured, using Hydrolab, Model "Multi 340I/SET".

\section{Laboratory analysis}

Water samples were analyzed for all selected variables according to the procedures specified in American Public Health Association (APHA, 1995) ${ }^{(11)}$. $\mathrm{CO}_{3}{ }^{2-}$ and $\mathrm{HCO}_{3}{ }^{-}$were measured titrimetrically against standard $\mathrm{H}_{2} \mathrm{SO}_{4}(0.02 \mathrm{~N})$ on the spot. Total dissolved solids (TDS) were determined by filtration of a volume of sample with glass micro fiber filter (GF/C) and a known volume of filtrate was evaporated at $180^{\circ} \mathrm{C}$. Dissolved oxygen was carried out by using the modified Winkler method. BOD was determined by using 5 days method. COD was carried out using potassium permanganate method. Water alkalinity was determined immediately after sampling collection using phenolphthalein and methyl orange indicators. chlorosity was measured using Mohr's method and sulphate by turbidimetric methods. Calcium and magnesium were determined by direct titration using EDTA solution. Total $\mathrm{Fe}, \mathrm{Mn}, \mathrm{Zn}, \mathrm{Cu}, \mathrm{Cd}$ and $\mathrm{Pb}$ in water were measured after digestion using an atomic absorption reader (Perkin Elmer 3110 USA) with graphite atomizer HGA-600.

\section{Results and Discussion}

\section{Physical parameters}

Temperature is a factor of great importance for aquatic ecosystem, as it affects the organisms, as well as, the chemical and physical characteristics of water ${ }^{(12)}$. Water temperature values ranged between minimum $15.8^{\circ} \mathrm{C}$ recorded at station VI 
during winter season and the maximum $30.3^{\circ} \mathrm{C}$ which was recorded at station IV during summer (Table 2). Electrical conductivity values in the Mediterranean coastal line showed high levels more than that reported in the Damietta estuary, due to the dilution effect by fresh water intrudes into the estuary throughout the Faraskour $\operatorname{Dam}^{(13)}$. The values were ranged in a narrow range $(1.62-9.21 \mathrm{mmhos} / \mathrm{cm})$ inside estuary but due to intrusion of sea water through the Boughaz inlet station VI recorded the highest values $(35.4 \mathrm{mmhos} / \mathrm{cm})$ in summer (Table 2).

TABLE 2. Range and mean values of the physical and chemical parameters at the studied area during 2008 .

\begin{tabular}{|c|c|c|c|c|}
\hline \multirow{2}{*}{ Parameters } & \multicolumn{2}{|c|}{ Damietta estuary } & \multicolumn{2}{|c|}{ Mediterranean shore } \\
\hline & Range & Mean & Range & Mean \\
\hline Temp. ${ }^{\circ} \mathrm{C}$ & $15.8-30.3$ & 22.5 & $14.5-31.6$ & 23.0 \\
\hline $\mathrm{EC} \mathrm{mS} / \mathrm{cm}$ & $53.4-62.4$ & 58.2 & $58.6-65.0$ & 62.1 \\
\hline $\mathrm{pH}$ & $7.5-8.9$ & 8.2 & $7.7-8.9$ & 8.3 \\
\hline $\mathrm{DO} \mathrm{mg} / \mathrm{l}$ & $3.9-8.3$ & 5.6 & $4.7-7.6$ & 6.1 \\
\hline BOD mg/l & $11.9-22.8$ & 16.6 & $2.3-3.8$ & 3.1 \\
\hline COD mg/l & $19.5-34.2$ & 25.3 & $9.1-16.3$ & 12.1 \\
\hline Total alkalinity mg/l & $149-197$ & 167.0 & $131-201$ & 165 \\
\hline $\mathrm{Cl} \mathrm{g} / \mathrm{l}$ & $22.1-24.6$ & 23.3 & $22.5-25.1$ & 24.0 \\
\hline $\mathrm{SO}_{4}{ }^{2-} \mathrm{g} / \mathrm{l}$ & $3.1-4.4$ & 3.8 & $3.8-4.4$ & 4.1 \\
\hline $\mathrm{Ca} \mathrm{mg/l}$ & $742-832$ & 785 & $756-860$ & 806 \\
\hline $\mathrm{Mg} \mathrm{g} / \mathrm{l}$ & $1.7-1.9$ & 1.8 & $1.8-2.0$ & 1.9 \\
\hline $\mathrm{Nag} / \mathrm{l}$ & $7.3-8.3$ & 7.8 & $7.6-8.6$ & 8.2 \\
\hline $\mathrm{K} \mathrm{mg/l}$ & $546-624$ & 585 & $586-643$ & 616 \\
\hline $\mathrm{NH}_{4}^{+} \mu \mathrm{g} / \mathrm{l}$ & $325-2231$ & 1350 & $312-398$ & 346 \\
\hline $\mathrm{NO}_{2}^{-} \mu \mathrm{g} /$ & $4.2-141$ & 79.6 & $1.5-5.8$ & 3.3 \\
\hline $\mathrm{NO}_{3} \mu \mathrm{g} /$ & $32.5-359$ & 205.0 & $19.5-37.6$ & 28.2 \\
\hline $\mathrm{PO}_{4}{ }^{3-} \mu \mathrm{g} /$ & $32.0-256.3$ & 124.8 & $26.0-39.4$ & 32.3 \\
\hline $\mathrm{TP} \mu \mathrm{g} / \mathrm{l}$ & $115-984$ & 463.0 & $106-161$ & 134 \\
\hline $\mathrm{SiO}_{3}{ }^{2-} \mathrm{mg} / \mathrm{l}$ & $1.5-2.9$ & 2.1 & $2.1-3.0$ & 2.5 \\
\hline $\mathrm{Fe} \mu \mathrm{g} / \mathrm{l}$ & $216-312$ & 268 & $174-406$ & 236 \\
\hline $\mathrm{Mn} \mu \mathrm{g} / \mathrm{l}$ & $38.0-72.0$ & 56.8 & $32.0-72.0$ & 49.8 \\
\hline $\mathrm{Zn} \mu \mathrm{g} / \mathrm{l}$ & $64.6-152.1$ & 107.2 & $54.2-120.8$ & 85.8 \\
\hline $\mathrm{Cu} \mu \mathrm{g} / \mathrm{l}$ & $3.9-11.4$ & 6.4 & $2.45-5.6$ & 3.8 \\
\hline $\mathrm{Pb} \mu \mathrm{g} / \mathrm{l}$ & $7.3-23.4$ & 16.7 & $5.65-12.3$ & 8.2 \\
\hline $\mathrm{Cd} \mu \mathrm{g} / 1$ & $0.65-2.3$ & 1.4 & $0.56-1.7$ & 1.0 \\
\hline
\end{tabular}

TP: Total phosphorus.

\section{Chemical parameters}

$\mathrm{pH}$ value is the master control parameter in aquatic environment for the chemical and biological transformation of water ${ }^{(14)}$. It controls the solubility of metal ions and affects natural aquatic life. The desirable $\mathrm{pH}$ for fresh water is in the range 6.5-9 for aquatic life ${ }^{(15)}$. The recorded $\mathrm{pH}$ values found in the alkaline side ranged between (7.61-8.67) and (7.5-8.67) in Damietta estuary and Mediterranean coastal shore, respectively. The relative decrease of $\mathrm{pH}$ values may be attributed to the lower activity of phytoplankton as wells as to bacterial and fungal action in the sediment,

Egypt. J. Chem. 55, No.1 (2012) 
these activities liberated methane and hydrogen sulphide as well as the formation of organic acids and other breakdown products ${ }^{(16)}$.

Dissolved oxygen values ranged between $(3.9-8.3 \mathrm{mg} / \mathrm{l})$ and $(4.6-7.8 \mathrm{mg} / \mathrm{l})$ in Damietta estuary and Mediterranean coastal shore, respectively (Table 2). Dissolved oxygen values were decreased by increase of water temperature during summer due to the decrease in the solubility of atmospheric oxygen and the increase of oxidative process of organic matter ${ }^{(17,18)}$. On the other hand, Damietta estuary has high values of both biological and chemical oxygen demand compared with their corresponding values in Mediterranean shore due to the various pollutants resulting from different human activities in this area. Their values fluctuated in the ranges of 12.6-22.8 and 2.3-3.8 for BOD in Damietta estuary and Mediterranean shore, respectively, where the corresponding ranges for COD were 19.5-34.2 and 9.1-16.3 mg/l (Table 3).

Egyptian Ministry of Health has set maximum limits of COD in the Nile water from southern parts until the end of its branches from 10 to $15 \mathrm{mg} / \mathrm{l}^{(19)}$. The present results have passed these values in several sites in Damietta estuary but in Mediterranean shore the COD levels were within the limits.

\section{Major anions}

Alkalinity values were fluctuated between 149-197 and 131-201 mg/l in Damietta estuary and Mediterranean shore, respectively. The obtained results showed narrow variation between two studied sectors; however there are regular increases in alkalinity values along the extent of Damietta estuary, as a consequence of the effect of bacterial decomposition of the organic substance, where bicarbonate and ammonia are the final products as mentioned by Metawea ${ }^{(20)}$.

On the other hand, chloride and sulphate concentrations varied between (22.1-24.6 \& 22.5-25.1) and (3.05-4.43 \& 3.81-4.43 mg/l), in Damietta estuary and Mediterranean shore, respectively (Table 2). It is clear from the above mentioned results that, chloride and sulphate levels in the Mediterranean coastal line exhibit the same trend as Damietta estuary, but its values were higher than the corresponding ones in the Damietta estuary. These observations declared that, both and sulphate concentrations in Damietta estuary depend on their levels in Mediterranean Sea.

\section{Major cations}

The levels of major cations results concenteration $(\mathrm{Na}, \mathrm{K}, \mathrm{Ca}$ and $\mathrm{Mg}$ ) in the Mediterranean coastal line exhibited similar trend as Damietta estuary. Furthermore, their values increased progressively while moving away from Damietta estuary to the sea which declared that major cations content of Damietta estuary depend on the intrusion of seawater to the estuary.

Nutrient salts

The dynamic distribution of dissolved nutrients in Damietta estuary was governed to great extent by mixing of estuary water with seawater. The 
absorption of nutrient on suspended particles and subsequent sedimentation to the overlying sediment also play a role in the distribution of nutrients in lake water.

The obtained results showed that the highest levels of nitrite were recorded in winter and ranged between $4.2-141.2 \mu \mathrm{g} / \mathrm{l}$ (Table 2), which are mainly attributed to oxidation of ammonia yielding nitrite as reaction intermediate especially in abundant oxygen during winter according to the following equation:

$$
\mathrm{NH}_{4}^{+}+1 \frac{1 / 2}{\mathrm{O}_{2}} \longrightarrow \mathrm{NO}_{2}^{-}+2 \mathrm{H}^{+}+\mathrm{H}_{2} \mathrm{O}
$$

Nitrate contents showed notable increase during summer season which may be related to the increase in evaporation rates and nitrification of $\mathrm{NH}_{3}$ and $\mathrm{NO}_{2}^{-}$ produced by the biochemical decomposition of descending dead planktons, proteins and their derivatives forming nitrate ${ }^{(21)}$. Furthermore, the obtained results showed obvious increase of ammonia values during hot seasons (summer and spring) due to the effect of the ammonification process of organic matter yielding ammonia by heterotrophic bacteria action ${ }^{(22)}$. The elevation of ammonia values in the Damietta estuary attributed to the high amount of agricultural runoff and domestic sewage inflow from the adjacent cultivated lands and neighboring villages, thus ammonia content exhibits progressive decrease while moving away from Damietta estuary to the sea (Table 2).

The obtained results of orthophosphate showed relative decrease during winter that attributed to sorption of phosphate onto the humic matter forming humic- iron -phosphate complexes (DHM- Fe- $\mathrm{PO}_{4}$ ), this reduces the total amount of available phosphate ${ }^{(23)}$.

The distribution pattern of nutrient salts in the Damietta estuary was differing completely than the Mediterranean Sea. The elevation of nutrient salts values in the estuary attributed to the high amount of agricultural runoff and domestic sewage inflow from the adjacent cultivated lands and neighboring villages. Furthermore, the nutrient salts content decreased progressively while moving away from Damietta estuary which declared that nutrient salts content of the Mediterranean Sea depends on its distribution pattern in Damietta estuary.

\section{Heavy metals}

Iron values were found in the range $(216-312)$ and $(174-406 \mu \mathrm{g} / \mathrm{l})$ in Damietta estuary and Mediterranean coastal shore, respectively (Fig. 2). The minimal values of iron were recorded during summer, which may be attributed to the iron adsorbed by clayey minerals, suspended matter, surface microorganisms, and metals oxide as iron oxide under high temperature. Also, high values of iron contents recorded during autumn may be related to the flood period effect, which lead to the leaching of iron from the banks of the River Nile as well as the great amount of fine grains and suspended particles containing iron element . 


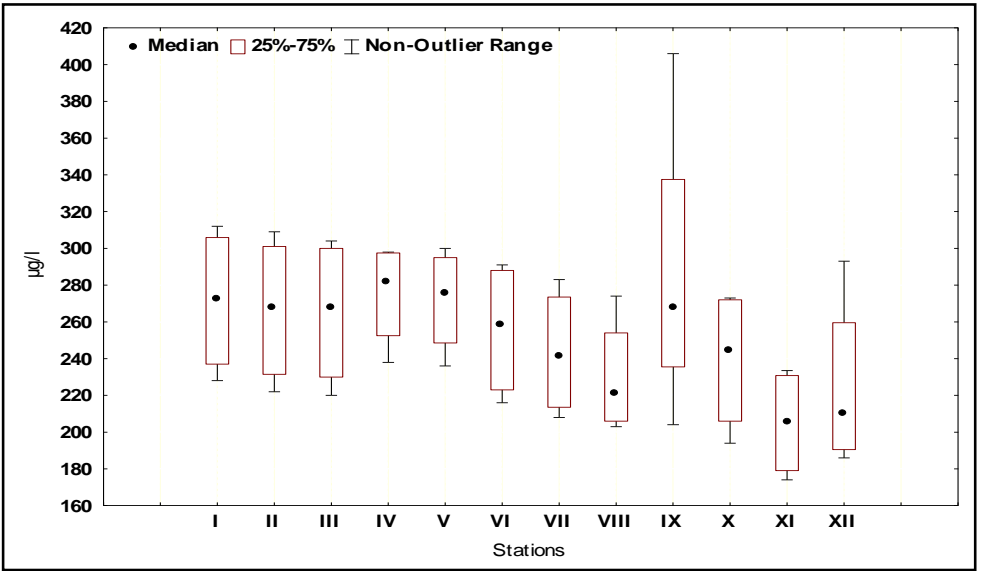

Fig. 2. Seasonal variation of iron $(\mu \mathrm{g} / \mathrm{l})$ in the studied area during 2008 .

Manganese concentrations fluctuated between 38-72 $\mu \mathrm{g} / \mathrm{l}$ at Damietta estuary compared with 32-72 $\mu \mathrm{g} / \mathrm{l}$ at Mediterranean coastal shore (Fig. 3). However, copper ranged between 3.9-11.3 $\mu \mathrm{g} / \mathrm{l}$ and 2.4 - 5.6 $\mu \mathrm{g} / \mathrm{l}$ at Damietta estuary and Mediterranean coastal shore, respectively (Fig. 4). The minimal value of zinc was recorded at station VI during summer and was found to be $65 \mu \mathrm{g} / \mathrm{l}$ while, the maximal value was recorded at station I $(152 \mu \mathrm{g} / \mathrm{l})$ in winter at Damietta estuary (Fig. 5). The relative increase in zinc concentrations during winter, may be attributed to the release of elements to the above water layers through drought period, where the water levels decreased and the degradation of the aquatic organisms and organic matter would be increased by the action of microbial activities ${ }^{(24)}$.

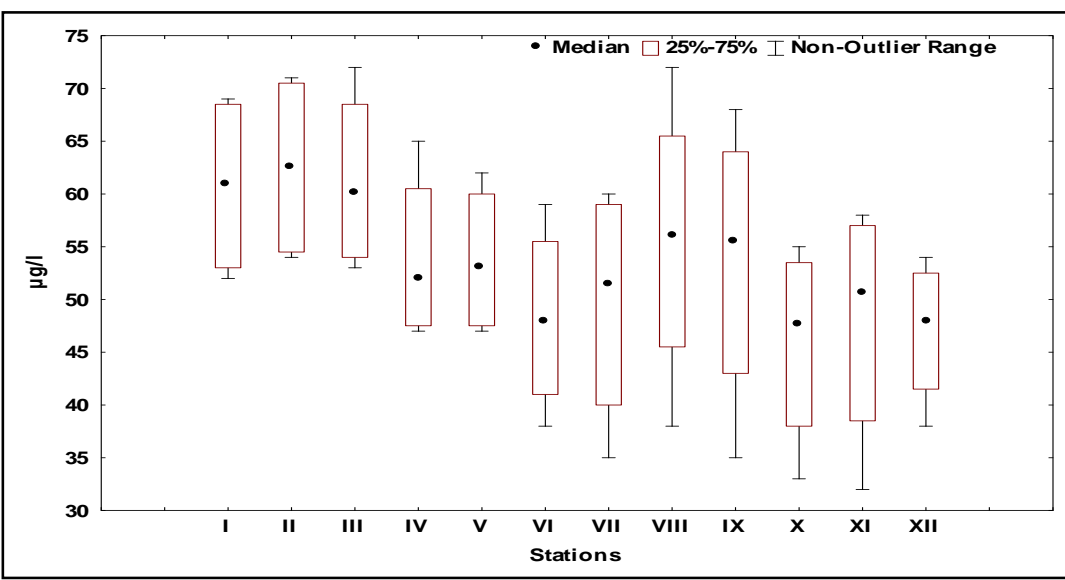

Fig. 3. Seasonal variation of manganese $(\mu \mathrm{g} / \mathrm{l})$ in the studied area during 2008. 


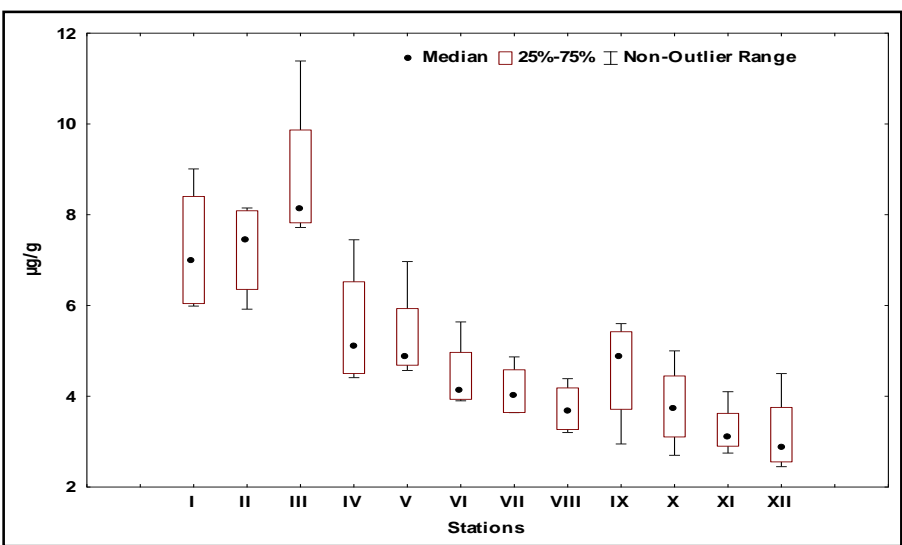

Fig. 4. Seasonal variation of copper $(\mu \mathrm{g} / \mathrm{l})$ in the studied area during 2008.

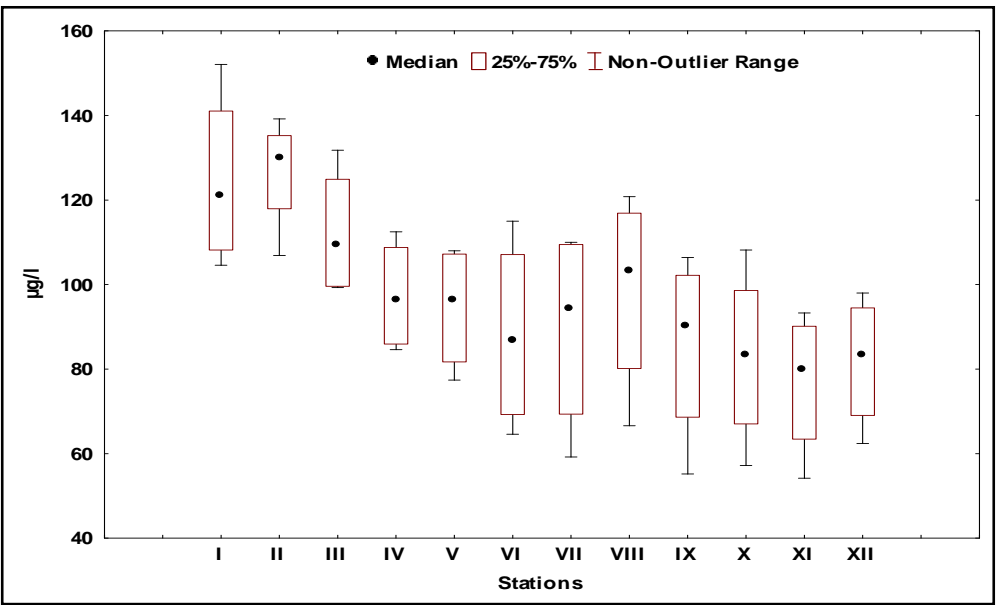

Fig. 5. Seasonal variation of zinc $(\mu \mathrm{g} / \mathrm{l})$ in the studied area during 2008.

The distribution pattern of lead in the sea water showed similar trend as Damietta estuary. This observation confirmed that the $\mathrm{Pb}$ content of the sea was dependent on the corresponding levels in the Damietta estuary. The values of lead concentrations increased in cold seasons and decreased in hot seasons due to adsorption of lead onto organic matter descending to the bottom sediment especially with high temperature. The minimal value of lead $(7.28 \mu \mathrm{g} / \mathrm{l})$ was recorded at station VI during summer. While the maximal value $(23.36 \mu \mathrm{g} / \mathrm{l})$ was recorded at station I, during winter (Fig. 6). Cadmium contents showed similar trend as lead, the lowest value of cadmium $0.65 \mu \mathrm{g} / \mathrm{l}$ was recorded during spring of station $\mathrm{V}$. The decreasing in cadmium concentrations during spring attributed to adsorption of cadmium onto organic matter ${ }^{(25)}$. While the highest value $2.34 \mu \mathrm{g} / \mathrm{l}$ was recorded during summer of station I (Fig. 7).

Egypt. J. Chem. 55, No.1 (2012) 


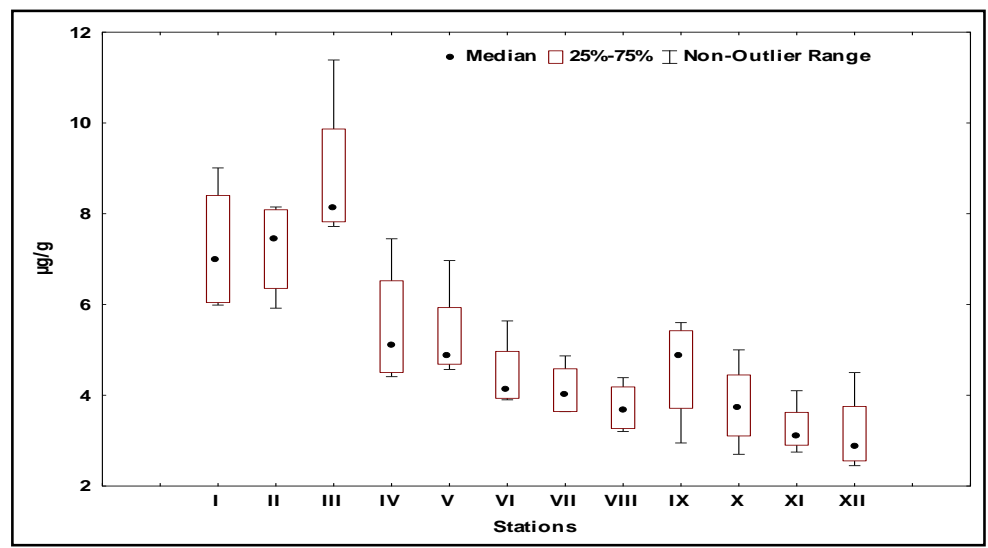

Fig. 6. Seasonal variation of lead $(\mu \mathrm{g} / \mathrm{l})$ in the studied area during 2008.

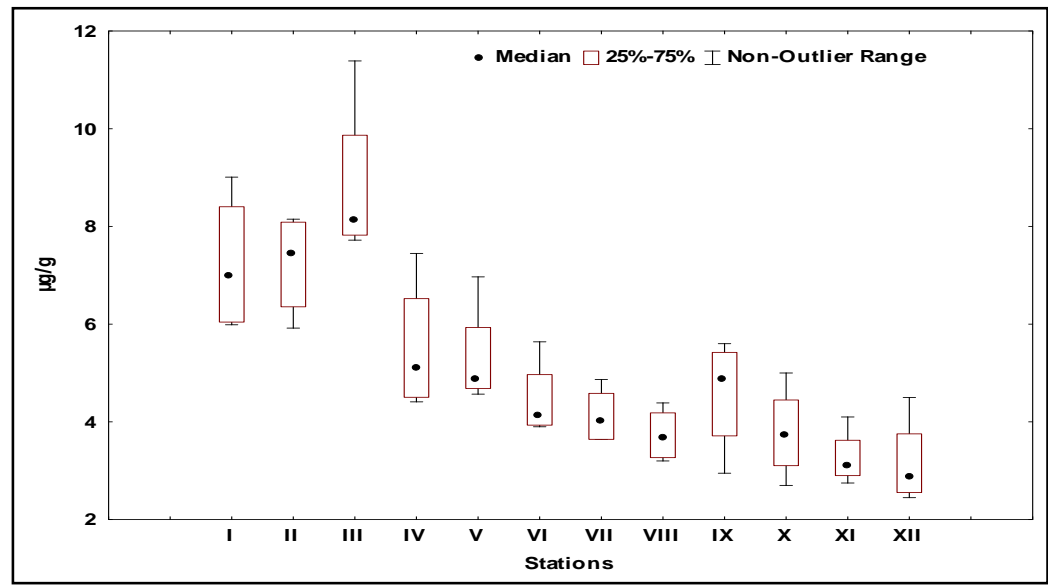

Fig. 7. Seasonal variation of cadmium $(\mu \mathrm{g} / \mathrm{l})$ in the studied area during 2008.

It is clear from the above mentioned results that heavy metals in the Damietta estuary were relatively different than those of the Mediterranean Sea. The elevation of heavy metals values in the estuary attributed to the high amount of agricultural runoff and domestic sewage inflow from the adjacent cultivated lands, neighboring villages, domestic wastes and industrial discharges inflow to the river. Furthermore, the heavy metals content decreased progressively while moving away from Damietta estuary to the sea.

\section{Referances}

1. Abdel Hamid, M.I., Shaaban-Dessouki, S.A. and Skulberg, O.M., Water quality of the River Nile in Egypt. 1. Physical and chemical characteristics. Archiv. Hydrobiol. 90, 283-310 (1992). 
2. Saad, M.A.H. and Goma, R.H., Effect of the High Dam and Aswan cataract on the chemical composition of the Nile water. I. Major anions. Verh. Internat. Verein. Limno. 25, $1812-1815$ (1994).

3. Fishar, M.R.A. and Khalifa, U.S.A. (Ed.): Status of biodiversity of River Nile, Workshop hold at the British Council, 9 December, Cairo, Egypt. 80pp. (2003).

4. James, M.C., Accumulation of lead in fish from Missouri streams impacted by lead mining. Bull. Environ. Contam. Toxicol. 34, 736 - 774 (1985).

5. Shaaban-Dessouki, S.A., Soliman, A.I. and Deyab, M.A., Environmental characteristics and nutrients distribution in Damietta Estuary of the River Nile. Journal of Environmental Science, 6 (1993).

6. Ali, M.H.H., Chemical and physical studies on the River Nile at Damietta branch region. M. Sci. Thesis, Fac. of Sci. Menofiya Univ. (1998).

7. EI Bouraie, M.M., El Barbary, A.A., Yehia M.M. and Motawea, E.A., Heavy metal concentrations in surface river water and bed sediments at Nile Delta in Egypt. Suo 61(1), 1-12 (2010).

8. Samecka-Cymerman, A. and Kempers, A.J., Concentrations of heavy metals and plant nutrients in water, sediments and aquatic macrophytes of anthropogenic lakes (former open cut brown coal mines) differing in stage of acidification. Sci. Total Environ. 281, 87-98 (2001).

9. Sanchez Lopez, F.J., Gil Garcia, M.D., Martinez Vidal, J.L., Aguilera, P.A. and Frenich, A.G., Assessment of metal contamination in Donana National Park (Spain) using crayfish (Procamburus Clarkii), Environ. Monitoring and Assessment, 93, 17-29 (2004).

10. Kotickhoff, S.W., Pollutant Sorption in Environmental Systems. EPA- 600ID, 80 83, NTTS, Spring Field, VA (1983).

11. American Public Health Association (APHA) Standard Methods of the Examination of Water and Waste Water. New York, 1193pp. (1995).

12. Delince, G., The Ecology of The Fish Pond Ecosystem With Special Reference to Africa. Text book, Kluwer Academic Publishers, 230pp. (1992).

13. Ali, M.H.H., Chemical and physical studies on the River Nile at Damietta branch region. M. Sci. Thesis, Fac. of Sci. Menofiya Univ. (1998).

14. Goher, M.E.M., Studies on the precipitation and dissolution of some chemical element in lake Qarun, Ph. D. Thesis. Fac. Sci., Al Azhar Univ., Egypt (2002).

15. Chin, D.A., Water-Resources Engineering. Prentice-Hall Inc. Upper Saddle River, New Jersey, 585-635 (2000).

16. Ravindra, K., Rani, M. and Kaushik, A., Seasonal variations in physico-chemical characteristics of River Yamuna in Haryana and its ecological best-designated use. $J$. Environ. Monit. 5, 419-426 (2003).

Egypt. J. Chem. 55, No.1 (2012) 
17. Rai, A.K., Limnological characteristics of subtropical lakes Phewa, Begnas and Rupa in Pokhara Valley. Nepal. Jpn J. Limnol, 1: 33 - 46 (2000).

18. Mahmoud, S.A., Evaluation of toxicity effect of some pollutants on histological feature and biochemical composition of Oreochromis niloticus L. living in River Nile, Damietta branch, Ph. D. Thesis, Fac. Sci., Benha branch, Zagazig Univ., Egypt (2002).

19. Sayed, M.F., Chemical studies of pollution in Rosetta branch of River Nile between Kafr El-Zayat and Rosetta outlet. Ph. D. Thesis, Fac. Sci., Cairo Univ. Egypt, 403pp. (2003).

20. Metawea, E.A.A., Monitoring and evaluation of some chemical parameters associated with changing the effluent rates on El-Rahawy drain and their impact on water quality of Rosetta branch, M. Sc. Thesis, Fac. Sci., Cairo University, Egypt (2009) .

21. Munawar, M., Limnological studies on freshwater ponds of Hyderabad India, I. The Biotope. Hydrobiol. 35, 127- 162 (1970).

22. Barat, S. and Jana, B.B., Effects of farming management on the distribution pattern of ammonification rate, protein mineralizing and ammonifying bacterial population in experimental culture tanks. Bamidgeh, 39 , 120 - 132 (1987).

23. Jones, R.I., Salonen, K. and DeHaan, H., Phosphorus transformation in the epilimnion of humic lakes: a biotic interaction between dissolved humic materials and phosphate. Freshwat. Biol. 19, 357-369 (1988).

24. Osman, M.A., Ali,M.H.H., Mohamed, M.A.M. and Al-Afify, A.D.G., Assessment of agriculture drainage water quality to be used for fish farm irrigation. Journal of Nature and Science, 8 (2), 1-15 (2010).

25. Tessier, A., Couraard, Y., Camphell, P.G.C. and Aullair, J.C., Modeling Cd partitioning in oxic lake sediments and $\mathrm{Cd}$ concentrations in the freshwater bivalve Anodonta grandis. Limnol. Oceanogr. 38, 1-17 (1993). 


\section{تـأثير مصـب فـرع دميـاط على الشـريط الســاحلى للبحر الأبـيض \\ المتوسط}

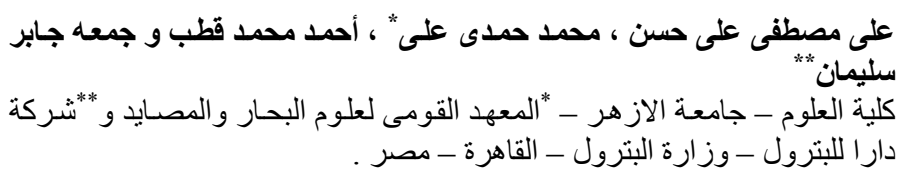

تهذف هذه الدراسة إلى استكمال الدراسات و الأبحاث الرامية إلى تقصى النواحى البحى

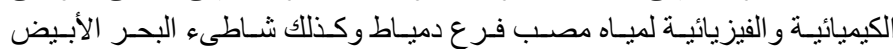

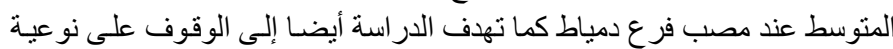

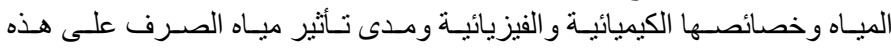
الخصائص بالإضافة إلى تعيين العناصر الثقيلة و التىى لها آثار تر اكمية في الثي أعضاء الأسماك المختلفة والنى تعيش فى مياه النهر.

ومن هذا المنطلق تم تجميع عينات الدراسة من فبر اير 2008 حتى نوفمبر

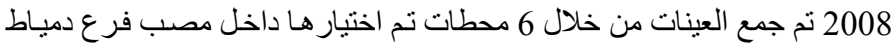

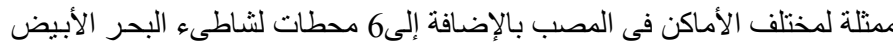

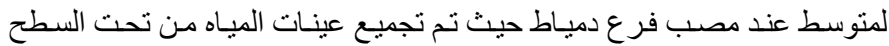

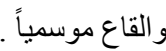

أظهرت الدراسة أن تركيز الأملاح المغذية و العناصر الثقيلة يعتمد على كمية

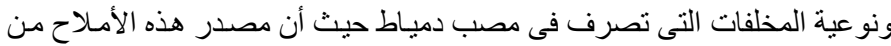
الصرف وبذلك تعتبر هذه الأملاح المغذية خارجية الصصدر . .

تركيز العناصـر الكيميائيـة والفزيائيسة تزداد فـى محطـات البحر عن النهرماعدا الأملاح المغذية المعادن الثقيلة.

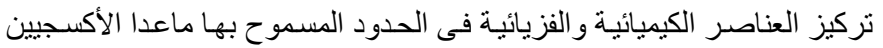

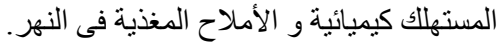
تركيز العناصر الثقيلة تزداد فى محطات النهر اعلى من البحر. 